\title{
Agglomeration Economies and Wellbeing: Evidence from India
}

\author{
By Arup Mitra*
}

\begin{abstract}
This paper argues that large cities by virtue of being more productive are able to offer better economic and non-economic opportunities. Even the slum residents located at the lower rungs of the socio-economic ladder are able to derive these benefits through income, education and health linkages. The well-being index constructed on the basis of certain economic, social, demographic, health and education specific variables collected through a primary survey in four cities shows its positive association with city size and its variation in relation to the nature of the city. The percentage of slum dwellers residing in the bottom size classes is lower in large and industrialized city compared to the ones which are stagnant and lack economic growth. However considerable poverty also exists in large cities notwithstanding agglomeration benefits and this makes a case for urban employment support programmes.
\end{abstract}

\section{Framework}

In the process of economic development urbanization and industrialization share a close nexus: not only industrialization leads to urbanization but also urbanization has productivity-augmenting effects on industry (Mills and Becker, 1986; Krugman, 1991; Fujita and Thisse, 2003; Kuchiki, 2005). When production was predominantly agricultural in pre-industrial society, it occurred outside the cities. This pattern got reversed as the industrial revolution progressed - manufacturing production emerged as the major activity occurring in inner city areas (Brotchie, Newton, Hall and Nijkamp, 1985). On the whole, economic development not only caused a shift in the composition of growth and occupational structure but also manifested itself in terms of locational shift of the population resulting in urbanization. Within the urban areas large cities because of agglomeration economies, manifesting themselves in terms of higher levels of productivity and technical efficiency are again considered better than the medium sized or small towns.

In relation to this view it has been widely noted that economic growth varies considerably across space; even within India, states have recorded different growth rates, which do not seem to have any tendency towards convergence in the long run (Sachs, Bajpai and Ramiah, 2002). Among several

${ }^{*}$ Professor, Institute of Economic Growth, India. 
factors that influence economic growth, industrial performance has been treated as the engine of growth implying that equalization of industrial productivity can bring in equalization of economic growth across space. And also states with higher rates of urbanisation reported higher rates of economic growth (Sachs, Bajpai and Ramiah, 2002), thus bringing out a close connection between industry and urban.

In the context of agglomeration economies it is noted that some industries induce concentration of economic activity as they exhibit high economies of scale in operation and there are others which benefit from concentration because of these external economies (Mills, 1967 and Henderson, 1986). Concentration not only strengthens the forward and backward linkages, but also reduces the cost of operation by developing complementary services. The effective price of infrastructure services declines if there is concentration of users of these services (Mohan, 1993). In all, interdependence of industries in terms of input-output linkages, ancillarization and availability of infrastructure contribute to the growth of agglomeration economies. The benefits of concentration can be attributed to the following factors (Hermansen, 1972): (a) substantial economies of investment expenditure - the investment for the whole complex is less than the sum of investment for each enterprise planned and located in isolation, (b) efficient production due to advantages of specialization, economies of large scale operation and organization of common managerial and infrastructural facilities, (c) possibility of jointly exploiting of the natural and raw material resources of the area of location, and (d) opportunities for close contact, rapid diffusion of technological innovations, and rapid overall development of the economy. The external economies, in general are divided into two categories: (a) urbanization economies and (b) localization economies ${ }^{1}$, resulting in productivity augmenting effects. Agglomeration effects are usually captured in terms of total population/work force/employment in a given industry or all industries (Mitra, 1999).

Since the large cities are characterized by higher levels of productivity the real wages are also higher therein. Even in the informal sector the wages due to forward and backward linkages between the sectors are higher. In fact, in a general equilibrium framework it can be conveniently demonstrated how the gains in the high productivity segments get transmitted to other sectors in the economy (Williamson, 1988).

\footnotetext{
${ }^{1}$ Localisation economies are external to the firm but internal to the industry and, as Henderson (1986) describes, reflect (1) economies of intra industry specialization where greater industry size permits greater specialization among firms in their detailed functions, (2) labour market economies where industry size reduces search costs for firms looking for workers with specific training relevant to that industry, (3) scale of communication among firms affecting the speed of adoption of new innovations, and (4) scale in providing public intermediate inputs tailored to the technical needs of a particular industry. The urbanization economies, on the other hand, are external to both firm and industry, and result from the general level of economic activity in that city or increase in total city population. While strong urbanization economies may lead to the development of diversified large areas, localization economies foster specialized metropolitan areas if these economies occur in combination with possibilities of inter-area trade.
} 
The technological progress that the world is witnessing at a rapid pace is now accessible to all areas thanks to the communication technology. However, its implementation and utilization at the fullest level is possible only when the support structure in terms of highly skilled manpower, adequate infrastructural facilities and the overall governance exists significantly (Mitra et. al. 2002). Since the large cities are usually better off from this angle, the outcomes are also more profitable. Ancillarisation and sub-contracting possibilities are sizeable in large cities as the number of firms is large and they tend to encourage interdependency in an attempt to pursue super-specialization and reduce cost (Mitra, 1999 and 2000).

It has been widely observed that among the low income households the existence of social networks for accessing job market information is widely prevalent (Mitra, 2004). In fact, these networks are the basis of their survival strategy. However, it has been observed when individuals operate through close relatives and other informal networks along the lines of caste and kinship bonds, they end up creating excess supplies of labour in certain pockets and thus the possibility for upward mobility becomes highly limited for both the contact person and the new entrant (Mitra, 2010). But in large cities the possibility of diversifying the networks at a later stage subsequent to the entry is much higher as new contacts develop through new friends, employers and so on.

The visibility of the civil society, the general awareness of the public and the watchful role played by the media help cultivate new networks and also assure higher returns to the networks pursued by the low income households. In large cities there are usually a number of labour recruitment centres (informal), and as the new contacts develop, individuals tend to access more than one labour recruitment centres simultaneously, which in turn raises the options leading to occupational mobility and the possibility of accessing higher incomes (Mitra, 2010). Better connectivity, cheap transport system and the availability of alternative modes of transport help individuals commute faster, which does not restrict them to secure jobs in the neighbourhood of where they reside. Labour exploitation in large cities is less as unions and various voluntary organizations in some form or the other safeguard the interest of the general public. The anonymity of individuals particularly from the point of view of those who belong to disadvantaged castes helps break the legacy of the caste-based occupations in a large city (Kumar, Kumar and Mitra 2009). The sense of urbanism is supposedly more prevalent in large cities which help people overcome the barriers of caste and other social hindrances and follow a more market oriented approach. From all this it may be inferred that individuals across various socio-economic sections benefit in terms of accessing sustainable livelihood more in a large urban settlement vis-à-vis small towns.

These views are, however, one-sided. There is an equally strong contestable literature suggesting considerable overlaps between informal sector employment and poverty in large cities. Since it is the urban economy which is usually supposed to provide opportunities for raising productivity by 
generating employment in the high productivity industrial sector and contributing towards eradicating abject poverty (Mills and Becker, 1986), rural to urban migration is usually directed towards the large cities (Kundu, 2006). The economy wide consequences of excess supplies of labour in relation to demand are manifested in the form of open unemployment, underemployment and low productivity, leading to large scale poverty in the cities. The rapid spread of slums resulting not merely from the shortage of housing but also from the low earnings of the workers engaged in low productivity activities has become an endemic feature of the urbanization process in the developing countries (Hoselitz, 1953 and Mitra, 1994). Also, the large cities are often pressed by several diseconomies of scale including congestion costs and greater land-rent prices.

Undermining the importance of agglomeration economies it is noted that the territorial division of labour between the urban and the rural areas is on the decline, in the developed countries especially. Similarly the differences between the economic structure in large urban settlements and that in mediumsized towns are about to disappear, lending little relevance to the agglomeration literature (Kamal-Chaoui, 2012) ${ }^{1}$. However, within the countries of Asia and the Pacific, despite a decline in poverty across the region, there are significant disparities between urban and rural areas and between regions within countries (United Nations, 2001). In the Indian context the rural-urban occupational distribution of labour is significantly different: while agriculture is still dominant in the rural areas most of the large scale manufacturing and modern service sector firms are concentrated in the urban localities (Mitra, 2013). In the backdrop of globalization the rural-urban distinction in sources of livelihood has grown much sharper. Economic globalization in an attempt to reap the cost advantages has motivated firms to diversify the production base across different countries depending on resource availability and this has led today to the emergence of a multi-centric world economy, as opposed to a centre and a periphery model of the earlier phase, and the increasingly pronounced convergence of emerging countries, led by China, India and Brazil (Huwart and Verdier, 2013). However, this has not resulted in any reduction in rural-urban growth differential in India and the differences in the sources of growth across rural and urban areas. Activities associated with economic globalization are highly dependent on infrastructure and human capital endowment (Mitra, Varoudakis and VeganzonesVaroudakis, 2002), which are not evenly distributed across space. Even within the urban areas the spatial inequalities in infrastructure availability are sharp, leading to greater concentration of activities in a handful of cities. Industrial and services hubs have emerged in a few locations which already had rich

\footnotetext{
${ }^{1}$ Kamal-Chaoui (2012) argues that among OECD urban areas medium-sized ones outgrow the rest since the mid-1990s. Medium-sized cities are half the economic size (GDP) of large ones; yet, they grow faster. Focusing on medium-sized cities are likely to result in higher economic growth and greater efficiency in metro-regions and larger urban areas, as they are often pressed by congestion costs, greater land-rent prices and other diseconomies of scale.
} 
infrastructural base and could subsequently attract further investment in those areas. Bangalore and Hyderabad are some of the glaring examples of this phenomenon. On the whole, economic globalization particularly in the Indian context has contributed to concentration of non-agricultural activities in the urban areas and again within the urban localities the external economies of scale are operating only in a few locations due to unequal distribution (Mitra and Mehta, 2011).

Given the possibilities of higher returns to investment and per capita incomes in large cities the present paper tries to verify if the well-being levels of those in the lower rungs are higher there compared to their counterparts in small towns. The direct and indirect linkages (including the secondary effects) exist through which the growth effects from one sector can percolate down to reach other peripheral sectors. The secondary effects are not just confined to the domain of employment generation: they may have spill-over effects in the areas of education and health as well. As workers in large cities can afford better quality education and health, the private suppliers of these services are also motivated to situate their firms in these locations. Though perfect competition does not prevail to bring down the prices of these services, oligopoly structure ensures reduction in super normal profits. All this results in higher wellbeing levels of the residents in large cities, including the ones placed at the bottom of the socio-economic ladder.

The paper is organized as follows. The following section deals with some of the demographic aspects of urbanization including the characteristics and the structure of class 1 cities which are considered to be the most dynamic component in the urban world. Section 3 deciphers some of the findings on poverty and wellbeing in slums based on the micro surveys in different types of cities, connecting the wellbeing issue to agglomeration economies. Finally the conclusion and policy issues are included in section 4. Research methodology includes factor analysis, explaining its relevance later in the text.

\section{Urbanisation in India}

The level of urbanization in the Indian context unlike the historical experience of several developed countries at comparable levels of per capita income and growth has been quite low. It increased sluggishly from 17.29 per cent in 1951 to 27.76 per cent in 2001 and 31.16 per cent in 2011 (Table 1). However, the rate of growth of urban population has been quite high notwithstanding a nominal increase in the per cent urban (Table 2). Demographers are quite concerned about this high rate of growth of urban population as it tends to create significant pressure on the infrastructure base. The number of cities and towns has also gone up considerably over the years, particularly over the last decade: from 5161 in 2001 to 7935 in 2011. 
Vol. 1, No. $1 \quad$ Mitra: Agglomeration Economies and Wellbeing: Evidence from India...

Table 1. Urbanization Level and Urban Growth

\begin{tabular}{|c|c|c|c|c|}
\hline Year & \% Urban & $\begin{array}{c}\text { No. of Cities } \\
\text { or Towns }\end{array}$ & $\begin{array}{c}\text { Rate of Growth } \\
\text { of Pop in } \\
\text { Urban Areas }\end{array}$ & $\begin{array}{c}\text { Rate of Growth } \\
\text { of Pop in All } \\
\text { Areas }\end{array}$ \\
\hline 1951 & 17.29 & 3035 & & \\
\hline 1961 & 17.97 & 2657 & 2.37 & 1.97 \\
\hline 1971 & 19.91 & 3081 & 3.29 & 2.24 \\
\hline 1981 & 23.34 & 3981 & 3.87 & 2.23 \\
\hline 1991 & 25.70 & 4615 & 3.16 & 2.16 \\
\hline 2001 & 27.79 & 5161 & 2.75 & 1.97 \\
\hline 2011 & 31.16 & 7935 & 2.7 & \\
\hline
\end{tabular}

Note: 1981 and 1991 figures include interpolated population estimates for Assam and Jammu and Kashmir respectively.

Source: Census of India, 2001, 2011 and also Premi (2006).

Though the number of cities and towns went up steadily, urban population in India is concentrated in big cities. For example, the class 1 cities (each with a population of 100,000 and above) constituted around 70 per cent of the total urban population in 2011. There were 384 urban agglomerations ${ }^{1}$ in 2001 which went up to 475 in 2011 . Further, 42.5 per cent of the total urban population lived in 53 metropolises (each with a population of I million and above) in 2011. Among the class I cities population distribution again seems to be highly unequal: only the top ten mega cities accounted for one-fourth of the total urban population in 2011. All this tends to suggest a highly unequal size distribution of urban population, i.e., large cities account for a large percentage of the urban population.

The definition of urban, particularly in the Indian context, seems to be quite broad and hence, it includes areas which still do not show any dynamism as the term urbanization is expected to indicate. One popular view in the context of urbanization suggests that only class 1 cities are to be considered as representative of urban characteristics and dynamism. In this section we, therefore, carry out a detailed study of 380 class 1 cities/urban agglomerations (as per the 2001 population census) in order to comment on their characteristics and asses how vibrant Indian urbanization has been. This is of course pursued in a very indirect manner by examining the question whether large cities offer better employment opportunities and a better demographic profile. This could not be done for more recent year (2011) as the detailed data are still awaited.

Keeping in view the limitations of the data we focus here on a set of variables which capture demographic, social and economic aspects. These variables are household size, female-male ratio, child-woman ratio, literacy, male and female work participation rate, percentage of work force engaged in non-agriculture activities excluding household manufacturing. Lower household size and child-woman ratio are desirable from demographic point of view. Literacy is likely to increase to reflect development. Similarly enhanced

\footnotetext{
${ }^{1}$ An urban agglomeration is defined as a continuous urban spread comprising one or more town and their adjoining outgrowths.
} 
work participation, particularly for females is indicative of higher social development and for males, better economic opportunities.

There is a clear cut positive relationship between the population size and the work participation rate, particularly that of males, possibly indicating that large cities offer greater work opportunities and hence, the worker to population ratio is higher in large cities than the rest (Table 2). Female literacy rate (among the population above six years) also indicates a positive relationship, mild though, with city size. On the other hand, household size tends to decline with city size. In terms of other demographic variables like female to male population ratio large cities, however, demonstrate a lower ratio which is possibly because of relatively higher magnitudes of single male inmigration to large cities. The child-woman ratio does not vary inversely with city size indicating no major variation in the fertility behaviour of the Indian urban population across various city sizes (Table 2 ).

Table 2. City Size and Certain Key Variables

\begin{tabular}{|c|c|c|c|c|c|c|c|c|}
\hline $\begin{array}{c}\text { Indep. } \\
\text { Var. }\end{array}$ & $\begin{array}{c}\text { Dep Var: } \\
\text { HHSZ }\end{array}$ & $\begin{array}{c}\text { Dep Var: } \\
\text { F/M } \\
\text { Ratio }\end{array}$ & $\begin{array}{c}\text { Dep Var: } \\
\text { Child/ } \\
\text { Woman }\end{array}$ & $\begin{array}{c}\text { Dep Var: } \\
\text { WPRM }\end{array}$ & $\begin{array}{c}\text { Dep } \\
\text { Var: } \\
\text { WPRF }\end{array}$ & $\begin{array}{c}\text { Dep Var: } \\
\text { OTHACTM }\end{array}$ & $\begin{array}{c}\text { Dep Var: } \\
\text { OTHACTF }\end{array}$ & FLIT \\
\hline POPSZ & $\begin{array}{c}-5.25 \mathrm{e}-08 \\
(-1.78)^{\mathrm{a}}\end{array}$ & $\begin{array}{c}-6.05 \mathrm{e}-06 \\
(-2.67)^{*}\end{array}$ & $\begin{array}{c}-1.39 \mathrm{e}-09 \\
(-0.79)\end{array}$ & $\begin{array}{c}5.18 \mathrm{e}-07 \\
(2.74)^{*}\end{array}$ & $\begin{array}{c}4.10 \mathrm{e}- \\
08 \\
(0.22)\end{array}$ & $\begin{array}{c}5.31 \mathrm{e}-07 \\
(2.33)^{*}\end{array}$ & $\begin{array}{c}1.20 \mathrm{e}-06 \\
(2.46)^{*}\end{array}$ & $\begin{array}{c}5.42 \mathrm{e}- \\
07 \\
(1.69)^{\mathrm{a}}\end{array}$ \\
\hline Constant & $\begin{array}{c}5.36 \\
(122.39)^{*}\end{array}$ & $\begin{array}{c}918.32 \\
(272.51)^{*}\end{array}$ & $\begin{array}{c}0.272 \\
(104.39)^{*}\end{array}$ & $\begin{array}{c}48.85 \\
(173.72)^{*}\end{array}$ & $\begin{array}{c}10.67 \\
(38.24)^{*}\end{array}$ & $\begin{array}{c}92.56 \\
(271.93)^{*}\end{array}$ & $\begin{array}{c}82.57 \\
(113.91)^{*}\end{array}$ & $\begin{array}{c}72.99 \\
(153.1)^{*}\end{array}$ \\
\hline $\mathrm{R}^{2}$ & 0.01 & 0.02 & 0.001 & 0.02 & 0.0001 & 0.01 & 0.02 & 0.005 \\
\hline
\end{tabular}

Note: No. of observation is 380 . '* and a' stand for significance at 5 and 10 percent levels respectively. HHSZ is household size, F/M female-male ratio, Child/Woman is child-woman ratio, WPRM and WPRF are work participation rates among males and females respectively, POPSZ is population size of the city, MLIT and FLIT are literacy rates among the male and female population respectively, SCSTM and SCSTF are the percentage of scheduled caste population among males and females respectively, OTHACTM and OTHACTF are the percentage of male and female (respectively) work force engaged in activities other than agriculture and household manufacturing.

Source: Based on population census, 2001.

The detailed information on employment structure is not available from the population census in the sense that several activities like non-household manufacturing, construction, trade and commerce, transport, storage and communication and community, social and personal services have been clubbed together. Only the activities like agriculture and household manufacturing have been reported separately. We may note that there is a positive association between city size and the relative size of the first group of activities, which are expected to constitute more demand-induced employment than the others (Tables 2). Also, in response to literacy, this group of activities varies positively, tending to supplement the view that large cities possibly have more demand-induced employment than their small counterparts. One of the important determinants of worker-population ratio and the so-called demand induced activities is city size, particularly in the case of males (Table 3). 
Vol. 1, No. $1 \quad$ Mitra: Agglomeration Economies and Wellbeing: Evidence from India...

Table 3. Determinants of Work Participation Rates and \% of Work Force Engaged in Non-household Manufacturing, Trade and Commerce, Transport, Storage and Communication and Community, Social and Personal Services

\begin{tabular}{|c|c|c|c|c|c|c|c|}
\hline $\begin{array}{l}\text { Indep. } \\
\text { Var. }\end{array}$ & $\begin{array}{c}\text { Dep } \\
\text { Var: } \\
\text { WPRM } \\
\end{array}$ & $\begin{array}{l}\text { Indep. } \\
\text { Var. }\end{array}$ & $\begin{array}{l}\text { Dep Var: } \\
\text { OTHACTM }\end{array}$ & $\begin{array}{l}\text { Indep. } \\
\text { Var. }\end{array}$ & $\begin{array}{c}\text { Dep } \\
\text { Var: } \\
\text { WPRF }\end{array}$ & $\begin{array}{l}\text { Indep. } \\
\text { Var. }\end{array}$ & $\begin{array}{l}\text { Dep Var: } \\
\text { OTHACTF }\end{array}$ \\
\hline SCSTM & $\begin{array}{l}-0.064 \\
(-1.85) \\
\end{array}$ & SCSTM & $\begin{array}{c}-0.03 \\
(-0.81) \\
\end{array}$ & SCSTF & $\begin{array}{c}0.09 \\
(3.31)^{*}\end{array}$ & SCSTF & $\begin{array}{c}0.16 \\
(2.57)^{*}\end{array}$ \\
\hline MLIT & $\begin{array}{c}0.199 \\
(4.84)^{*}\end{array}$ & & $\begin{array}{c}0.34 \\
(6.05)^{*}\end{array}$ & FLIT & $\begin{array}{l}-0.002 \\
(-0.06)\end{array}$ & FLIT & $\begin{array}{c}0.67 \\
(8.96) *\end{array}$ \\
\hline \multirow[t]{5}{*}{ POPSZ } & $\begin{array}{c}4.58 \mathrm{e}- \\
07 \\
(2.49)^{*} \\
\end{array}$ & POPSZ & $\begin{array}{c}5.04 \mathrm{e}-07 \\
(2.43)^{*}\end{array}$ & $\mathrm{~F} / \mathrm{M}$ & $\begin{array}{c}0.03 \\
(6.59)^{*}\end{array}$ & $\mathrm{~F} / \mathrm{M}$ & $\begin{array}{c}-0.04 \\
(-3.95)^{*}\end{array}$ \\
\hline & & HHSZ & $\begin{array}{c}-2.19 \\
(-3.24)^{*}\end{array}$ & $\begin{array}{l}\text { CHILD/ } \\
\text { WOMAN }\end{array}$ & $\begin{array}{c}-33.05 \\
(- \\
4.83)^{*}\end{array}$ & $\begin{array}{l}\text { CHILD/ } \\
\text { WOMAN }\end{array}$ & $\begin{array}{l}-11.43 \\
(-0.64)\end{array}$ \\
\hline & & WPRM & $\begin{array}{c}-0.31 \\
(-3.35)^{*}\end{array}$ & & & WPRF & $\begin{array}{c}-1.55 \\
(-12.58)^{*} \\
\end{array}$ \\
\hline & & & & & & POPSZ & $\begin{array}{c}4.09 \mathrm{e}-07 \\
(1.15)\end{array}$ \\
\hline & & & & & & HHSZ & $\begin{array}{c}-5.43 \\
(-5.90) *\end{array}$ \\
\hline Constant & $\begin{array}{c}32.57 \\
(9.22)^{*}\end{array}$ & Constant & $\begin{array}{c}90.85 \\
(8.45)^{*}\end{array}$ & Constant & $\begin{array}{c}-6.32 \\
(-1.02) \\
\end{array}$ & Constant & $\begin{array}{l}116.26 \\
(7.97)^{*}\end{array}$ \\
\hline R2 & 0.08 & & 0.20 & & 0.34 & & 0.51 \\
\hline
\end{tabular}

Note: No. of observation is 380. For variables' names and other notes see Table 4a.

Source: Based on population census, 2001.

In order to highlight the association between several variables simultaneously the factor analysis is considered to be appropriate as it does not get into the cause-effect relationship though at the same time it churns out the commonalities among different variables. A statistically significant factor deciphers the variables which tend to have strong association among themselves. This is reflected in terms of the coefficient of the variables known as factor loadings, the absolute value of which can vary from 0 to 1 . Variables with factor loadings closer to modulus 1 are treated to be dominant and the ones with closer to 0 are insignificant.

The results of the factor analysis (Table 4) corroborate the patterns which we observed from the regression analysis. The work participation rate, literacy and the dynamic component of the activities are positively associated with each other which are in turn negatively related to household size and childwoman ratio. In other words, the development indicators scattered over various dimensions are in a sense inter-related. With rise in literacy the work participation improves and so also the probability to access jobs in relatively dynamic activities. As participation in productive jobs rises fertility tends to decline which is reflected in lower household size and the child-woman ratio. The cluster analysis has been carried out to examine if the groups formulated on the basis of the magnitudes of the attributes have a geographical correspondence. Based on the data set for 380 class 1 cities/urban agglomerations around twenty groups can be identified. It is, however, quite difficult to decipher any systematic pattern in relation to their geographic location. 
Table 4. Results from Factor Analysis

\begin{tabular}{|c|c|c|}
\hline Variables & Factor 1 & Factor 2 \\
\hline HHSZ & -0.842 & 0.168 \\
\hline F/M & 0.446 & -0.378 \\
\hline CHILD/WOMAN & -0.813 & 0.186 \\
\hline MLIT & 0.764 & 0.241 \\
\hline FLIT & 0.825 & 0.176 \\
\hline WPRM & 0.646 & -0.386 \\
\hline WPRF & 0.556 & -0.465 \\
\hline OTHACTM & 0.367 & 0.585 \\
\hline OTHACTF & 0.327 & 0.659 \\
\hline SCSTM & 0.178 & 0.563 \\
\hline SCSTF & 0.193 & 0.570 \\
\hline
\end{tabular}

Note: No. of observations: 380. \% Explained: 54.09. For variables' names see Table 4a. Source: Based on population census, 2001.

\section{Well-being of the Low Income Households}

The next issue relates to the well-being levels of the population in different types of cities with the underlying hypothesis that agglomeration economies in large cities get translated into higher wellbeing levels. Higher agglomeration economies reflected in terms of higher productivity levels and real earnings imply greater affordability. Nutritional status and accessibility to education and health improve which in turn contribute to the overall wellbeing levels of the households. Fertility behaviour for example changes and so also the indicators of social development as education levels and health outcomes tend to improve.

However, due to the lack of data for the total city population we had to examine this hypothesis indirectly. The question that we pose is are the households from low income households better off in large cities compared to their counterparts in relatively small ones? On the aspect of poverty and wellbeing not much information is available at the city level from the secondary sources. However, under the UNDP-sponsored project on urban poverty one survey was undertaken in four cities of different population size and economic activities (i.e. Jaipur, Ludhiana, Mathura and Ujjain) ${ }^{1}$. These cities were picked up from the list of sixty-four cities prepared specifically for the urban renewal mission (JNNURM). The primary survey enables us to comment on certain aspects of well-being of the slum dwellers in these four cities. While Jaipur and Ludhiana are two million plus cities, Mathura and Ujjain are relatively small in size. Again, Ludhiana is an industrial city while Jaipur being a state capital, a tourist centre and also a trade centre has a significant spread of the services sector. Mathura and Ujjain are both religious cities and between the two the latter is absolutely stagnant. Such a mix of cities enables us to perceive wellbeing of the slum dwellers in a context which involves large variations.

${ }^{1}$ This project and survey sponsored by UNDP-GOI were undertaken by the Institute of Economic Growth, Delhi. 
From the measurement point of view various dimensions of poverty, rather than only income or consumption poverty, need to be considered to assess well-being. However, we could consider only those dimensions which are quantifiable. The following variables have been combined to construct the household specific well-being index: household size (HHSZ), child-woman ratio (CWR), per capita consumption expenditure ${ }^{1}$ (PCE), proportion of persons in the household who reported illness (ILL), percentage of household members who acquired at least primary level education (PRIM), percentage of members in the age group 15 to 59, which is a proxy for adult potential earners (PER15-59), percentage of working individuals (WM), age of the household head/principal earner taken as a proxy for experience in the job market (AG), health expenditure per capita (HPC), and per capita household income (HHPCI).

Household size is likely to reduce the well-being because the earnings and the related gains get distributed among a large number of individuals with an increase in the number of members. Similarly households with greater childwoman ratio indicate a higher rate of fertility and thus the economic gains get shared among a large number of children. As the percentage of ill members in the household rises, the income loss due to work-loss and, also, extra expenditure for curative purposes tend to increase, reducing the wellbeing level of the household. Health expenditure per capita on a priori basis may raise the well-being of the household if it is incurred for protective purposes, enhancing productivity. On the other, it may reduce well-being if it is incurred at the expense of consumption of essential items.

The other variables are expected to improve well-being. Per capita household income (HHPCI) and per capita consumption expenditure (PCE) raise the wellbeing because higher income and higher consumption enhance the accessibility to better quality life and health. Similarly with a rise in the percentage of household members who acquired at least primary level education (PRIM) the accessibility to better jobs and incomes and also awareness about heath and children's education improves. The percentage of members in the age group 15 to 59 which is a proxy for adult potential earners (PER15-59), the percentage of working individuals (WM), and the age of the household head/principal earner which is a proxy for experience in the job market (AG) contribute to household income positively.

Since these variables are heterogeneous, it is difficult to combine them to indicate an overall living standard of the households. Hence, factor analysis was conducted, and using the factor loadings as weights, variables were combined to generate a composite index of well-being, denoted as WELLINDEX(i). This was repeated for each of the significant factors (factors with eigenvalues greater than one):

\footnotetext{
${ }^{1}$ It excludes health expenditure.
} 


$$
W E L L I N D E X(i)=\sum_{j=1}^{n} F \operatorname{Lj}(i) X j
$$

where, FL is the factor loading, $\mathrm{j}=1 \ldots \mathrm{n}$ corresponding to the number of variables, and i represents the ith significant factor.

In the second stage the composite indices generated on the basis of factor loadings for each of the significant factors were combined using the proportion of eigenvalues as weights:

$$
W E L L I N D E X=\sum_{i=1}^{k}\left[\frac{E V(i)}{\sum E V(i)}\right] \quad W E L L I N D E X(i) k<n
$$

where, $\mathrm{i}$ ranges from 1 to $\mathrm{k}$, the number of significant factors.

Using the varimax rotation technique (in order to obtain statistically independent factors), results of the factor analysis are derived which suggest the presence of only one significant factor in each of the four cities (Table 5). The factor loading of household size takes a negative sign, which suggests that it reduces the well-being of the households. Household income per capita and consumption expenditure per capita both take positive factor loadings though in terms of magnitude they are moderate like that of household size. On the higher side are child-woman ratio, percentage of household members in the age bracket 15 to 59 and proportion of the number of working members to the total household size. While the child-woman ratio reduces the well-being as reflected in terms of negative factor loadings, the other two variables take a positive coefficient. Education, though highly moderate in terms of magnitude, shows a positive effect except in Jaipur. Health expenditure per capita also shows a positive effect though magnitude of the factor loadings is quite low.

Table 5. Factor Loadings from the Significant Factor

\begin{tabular}{|c|c|c|c|c|}
\hline Variables & Jaipur & Ludhiana & Mathura & Ujjain \\
\hline HHSZ & -0.24249 & -0.2870 & -0.23875 & -0.21306 \\
\hline PCE & 0.31847 & 0.36047 & 0.39325 & 0.36662 \\
\hline PRIM & -0.09208 & 0.17426 & 0.14379 & 0.14023 \\
\hline HHPCI & 0.34237 & 0.30792 & 0.28774 & 0.34142 \\
\hline HPC & 0.04937 & 0.10 & 0.15056 & 0.10359 \\
\hline CWR & -0.65278 & -0.84593 & -0.81161 & -0.79265 \\
\hline ILL & 0.06632 & 0.0145 & 0.06734 & 0.03419 \\
\hline PER15-59 & 0.77230 & 0.78747 & 0.78868 & 0.77967 \\
\hline AG & 0.16166 & 0.09205 & 0.20811 & 0.15901 \\
\hline WM & 0.61494 & 0.43949 & 0.39971 & 0.32805 \\
\hline \multirow{2}{*}{ Eigenvalue } & 2.255 & 2.8278 & 2.484 & 2.4205 \\
& $(22.55)$ & $(22.28)$ & $(24.84)$ & $(24.205)$ \\
\hline
\end{tabular}

Note: Figures in parentheses represent the percentage of total variation explained by the significant factor.

The well-being index has been constructed using the factor loadings as weights. It indicates that in Jaipur and Ludhiana 26 and 32 per cent of the slum 
households respectively are located in the bottom two size classes (Table 6). However, in Mathura and Ujjain, which are much smaller than the other two cities and also lack growth dynamism, the corresponding figures are 57 and 61 per cent respectively. Thus the well-being index even among the low income households seems to have a positive association with city size and it tends to vary with the nature of the city. It is interesting to note that these figures are substantially lower than the incidence of consumption poverty, which is 66.8 per cent in Jaipur, 43.6 per cent in Ludhiana, 75 per cent in Mathura and 88.2 per cent in Ujjain. This would tend to suggest that even when consumption poverty is high, many other facilities which are available in the cities contribute to the well-being of the population. However, we may note that even in the so-called dynamic cities the percentage of slum households located in the bottom size classes is not negligible either, suggesting that growth alone cannot eradicate poverty.

Table 6. Size Distribution of Households as per the Well-being Index

\begin{tabular}{|c|c|c|c|c|c|}
\hline Size Class & Jaipur & Ludhiana & Mathura & Size Class & Ujjain \\
\hline Upto 200 & 1.2 & 3.6 & 7.6 & Upto 200 & 8 \\
\hline $201-400$ & 24.6 & 28.2 & 49.2 & $201-400$ & 53 \\
\hline $401-600$ & 37.4 & 29.8 & 24 & $401-600$ & 27.4 \\
\hline $601-1000$ & 27.8 & 25 & 14.2 & $601-800$ & 8.8 \\
\hline $1001-1500$ & 6.6 & 9.2 & 3.6 & 800 and above & 2.8 \\
\hline 1501 and above & 2.4 & 4.2 & 1.4 & & \\
\hline
\end{tabular}

\section{Conclusion}

Large cities are said to be more productive: more demand-induced employment opportunities are available in large cities which grow in response to large quantum of investment undertaken therein. In terms of several socioeconomic development indicators we verified that they tend to improve with a rise in city size. Economic globalization has not reduced the intra-urban or rural-urban growth differentials. The agglomeration economies continue to exist because the new forces in the present context of economic globalisation have emerged to substitute the forces which explained their prevalence around two decades back and have been on the decline. This is, however, not to deny the considerable overlaps that may exist between informal sector employment, poverty, slums and other disamenities in large cities.

In the next step we tried to assess if the wellbeing of those in the low income households tends to vary across cities. Since the large cities are more productive as reflected in terms of a wide range of socio-economic indicators the low income households in large cities are likely to be better-off in large cities relative to their counterparts in small urban settlements. Based on a wide range of variables the wellbeing index has been computed for each of the slum households in the sample. Micro evidence suggests that large cities tend to improve the wellbeing of the population even among the low income 
households. The percentage of slum households at the bottom size classes is much larger in the stagnant and small urban settlements compared to the large and relatively dynamic ones. However, several of the sample households even in large cities are located in the bottom size classes. For them to experience an upward mobility the urban employment programmes are pertinent. Most of the urban specific programmes in India largely emphasize the importance of basic amenities to the urban poor and infrastructure need of the cities. However, safety-net for the low productivity urban informal sector workers is essential for reducing the intensity and the incidence of urban poverty. Besides, improvement in health and educational support can have long lasting effect on poverty.

\section{References}

Brotchie, J. P. Newton, P. Hall and P. Nijkamp, (1985), The Future of Urban Form: The Impact of New Technology, Routledge, London.

Fujita, M. and Thisse, J.-F. (2003). Does geographical agglomeration foster economic growth? And who gains and loses from it? The Japanese Economic Review 54, 121-145.

Henderson, J. V. (1986). Efficiency of resource usage and city size. Journal of Urban Economics 19, 47-70.

Hermansen, T. (1972), "Development Poles and Related Theories: A Synoptic Review," in N. M. Hansen (ed.) Growth Centers in Regional Economic Development, The Free Press, New York.

Hoselitz, B. (1953) "The Role of Cities in the Economic Growth of Underdeveloped Countries", Journal of Political Economy, Vol. 61, No.3.

Huwart, J.Y. and L. Verdier (2013), Economic Globalisation: Origins and Consequences, OECD Insights, OECD Publishing, http://dx.doi.org/10.1787/ 9789264111899-en

Kamal-Chaoui, L. and Sanchez-Reaza, J. (eds.) (2012), "Urban Trends and Policies in OECD Countries”, OECD Regional Development Working Papers 2012/01, OECD Publishing, http://dx.doi.org/10.1787/5k9fhn1ctjr8-en

Krugman, P. (1991), Increasing returns and economic geography. Journal of Political Economy 99, 483-499.

Kuchiki, A. (2005). Theory of a flowchart approach to industrial cluster policy. Discussion Paper Series, Institute of Developing Economies-JETRO No. 36.

Kundu, Amitabh (2006), Urbanisation and Urban Governance: Search for a Perspective Beyond Neo-Liberalism", in A. Shaw (ed.) Indian Cities in Transition, Orient Longman, Hyderabad.

Kumar, R., S. Kumar and Arup Mitra (2009) Social and Economic Inequalities: Contemporary Significance of Caste in India, Economic and Political Weekly, December 12, 2009 vol xliv no 50,

Meyer, D.R.(1998), "World Cities As Financial Centres", in F.-C. Lo and Y. M. Yeung (eds.) Globalization and the World of Large Cities, United Nations University Press, Tokyo.

Mills, E. S. (1967). An aggregate model of resource allocation in a metropolitan area. American Economic Review 57, 197-210. 
Vol. 1, No. $1 \quad$ Mitra: Agglomeration Economies and Wellbeing: Evidence from India...

Mills, E.S. and C.M. Becker (1986), Studies in Indian Urban Development, Oxford University Press, World Bank Research Publication

Mills, E. S. and B. W. Hamilton (1994), Urban Economics, $5^{\text {th }}$ Ed. Glenview, IL: Scott Foresmen.

Mills, E. S. and Arup Mitra (1997), Urban Development and Urban Ills, Commonwealth Publishers, Delhi.

Mitra, Arup, (1994), Urbanisation, Slums, Informal Sector Employment and Poverty: An Exploratory Study, B. R. Publishing Corp.

Mitra, Arup (1999), "Agglomeration Economies As Manifested in Technical Efficiency at the Firm Level", Journal of Urban Economics, Vol. 45, 490-500.

Mitra, Arup (2000), "Total Factor Productivity Growth and Urbanization Economies: A Case of Indian Industries," Review of Urban and Regional Development Studies, Vol. 12.

Mitra, Arup, Aristomene Varoudakis and Marie-Ange Veganzones- Varoudakis (2002), "Productivity and Technical Efficiency in Indian States' Manufacturing: The Role Infrastructure," Economic Development and Cultural Change, 50.

Mitra, Arup (2007), "Industry-Urban Nexus: The Role of Agglomeration Economies," in A. Shaw (ed.) Indian Cities in Transition, Orient Longman, Hyderabad.

Mitra, Arup (2010), Migration, Livelihood and Well-being: Evidence from Indian City-Slums, Urban Studies, Volume 47, No.7.

Mitra, Arup (2013), Insights into Inclusive Growth, Employment and Wellbeing in India, Springer, Delhi.

Mitra, Arup and Barjor Mehta (2011), "Cities as the Engine of Growth: Evidence from India", Vol. 137, No. 2, June 1, 171-183.

Mohan, Rakesh, (1993), Industrial Location Policies and Their Implications for India, Paper No. 9, Ministry of Industry, Office of the Economic Adviser, Government of India.

Papola, T. S. (1981). Urban informal sector in a developing economy. Vikas Publishing House.

Premi, M. K.(2006), Population of India: In the New Millennium: Census 2001, National Book Trust India, New Delhi.

Sachs, Jeffrey D., Nirupam Bajpai and Ananthi Ramiah (2002), "Understanding Regional Economic Growth in India," CID Working Paper No. 88, Center for International Development at Harvard University, March 2002.

United Nations (2001), Reducing Disparities: Balanced Development of Urban and Rural Areas and Regions within the Countries of Asia and the Pacific, Economic and Social Commission for Asia and the Pacific.

Willimason, J. (1988), "Migration and Urbanisation," in H. Chenery and T.N. Srinivasan (eds.) Handbook of Development Economics, Vol. I, Elsevier Science Publishers, B.V. 